\title{
The contingent role of distributed leadership in the relationship between HR practices and organizational ambidexterity in the cross-border M\&As \\ of emerging market multinationals
}

\section{Rekha Rao-Nicholson}

Senior Lecturer in International Management, Bristol Business School, University of the West of England

Bristol, UK

Email: rekha.nicholson@uwe.ac.uk

Zaheer Khan

Reader (Associate Professor) in International Business, Department of Strategy \& International Business, Kent Business School, The University of Kent, Kent, UK

Email: khan.zaheer@gmail.com

\section{Pervaiz Akhtar}

Senior Lecturer (Associate Professor) in Supply Chain/Logistics/Operations Management, The Logistics Institute, Hull University Business School,

The University of Hull, Hull,UK

Email: pervaiz.akhtar@hull.ac.uk

Shlomo Y. Tarba

Reader (Associate Professor) in Business Strategy, Strategy \& International Business, Birmingham Business School

The University of Birmingham, Birmingham, UK

Email: tarba2003@gmail.com

Note: This is a post review accepted version. Please cite: Rao-Nicholson, R., Khan, Z.,

Akhtar. P., \& Tarba, S. (2016). The contingent role of distributed leadership in the relationship between HR practices and organizational ambidexterity in the cross-border M\&As of emerging market multinationals, The International Journal of Human Resource Management, Doi: 10.1080/09585192.2016.1216882 


\begin{abstract}
This paper investigates the effect of human resource practices on organizational ambidexterity in cross-border mergers and acquisitions. Previous research suggests that human resource practices play an important role in improving organizational performance, but that there may be contingency factors that interact with human resource practices, leading to different performance outcomes. We focus on one such potential contingency factor: distributed leadership as a key moderator that interacts with human resource practices, leading to organizational ambidexterity in cross-border mergers and acquisitions. We examine 84 deals of emerging economies cross-border mergers and acquisitions. We found that human resource practices positively influence the acquired firms' ambidexterity, but when we take into account the contingent role of distributed leadership, the effect of human resource practices becomes much stronger, indicating the importance of distributed leadership as a key variable that can explain variations in the success of cross-border mergers and acquisitions. The findings have important implications for international human resources management practices in the acquired subsidiaries and for individual leadership styles adopted by parent firms during the post-acquisitions period.
\end{abstract}

Keywords: emerging economies, HR practices, organizational ambidexterity, mergers and acquisitions, distributed leadership. 


\section{Introduction}

Merger and acquisition (M\&A) activities involving emerging economies multinationals (EMNEs) have considerably increased in the last few decades (Luo and Tung, 2007, Aybar and Ficici, 2009, Kohli and Mann, 2012). It is now well established that M\&A activities take place in waves; for instance, the rapid growth of M\&As in the 1990s and early 2000s was followed by further increase in the EMNE activity after the global financial crisis (RaoNicholson and Salaber, 2015). Some M\&As by EMNEs, especially in the developed markets, were aimed at acquiring strategic assets, including the acquisition of managerial practices, processes, and high technology (Huang and Khanna, 2003, Purushothaman, 2004, Kumar, 2008, Gubbi, Aulakh, Ray, Sarkar and Chittoor, 2010, Hattari and Rajan, 2010). But performance studies examining the M\&A process in general (Rottig, 2013; Weber and Tarba, 2013; Rottig, Reus, and Tarba, 2014) and EMNE M\&As in particular, did not pay sufficient attention to the primary human resource $(\mathrm{HR})$ practices that can cause outcome differences between the M\&As and affect their ambidexterity (Rao-Nicholson, Khan and Stokes, 2015).

Most M\&As fail to achieve their set objectives, including post-acquisition integration and performance (Haleblian, Devers, McNamara, Carpenter and Davison, 2009, Gomes, Weber, Brown and Tarba, 2011, Weber, Tarba and Reichel, 2011, Gomes, Angwin, Weber and Tarba, 2013). One of the key criticisms of these studies is that they do not fully capture the role of human actors in M\&A performance: for example, the role of HR practices and of EMNE leadership in organizational ambidexterity (Rao-Nicholson et al., 2015). EMNE leadership is crucial for the success of cross-border M\&As (Rao-Nicholson et al., 2015). Altogether, there is limited focus on the emerging distributed leadership in the literature (Bolden, 2011, Thorpe, Gold and Lawler, 2011). The distributed leadership perspective acknowledges that there are multiple leaders (Spillane, Halverson and Diamond, 2004). This type of leadership could influence greatly the formalized HR practices in the area of 
organizational ambidexterity in the post-acquisition period. Distributed leadership, organized around shared goals and responsibilities, is pertinent for cross-border M\&As because firms must decide on their common objectives for their post-acquisition integration (Larsson and Finkelstein, 1999, Waldman and Javidan, 2009, Thorpe et al., 2011). Most studies have focused on traditional leadership styles, such as transformational and transactional, although the importance of the distributed leadership has been acknowledged recently (Bolden, 2011, Thorpe et al., 2011), and efforts are under way to investigate its role in cross-border M\&As.

Distributed leadership on the part of the acquirer firms is critical for effective management of HR practices in the subsidiaries, as leadership style is important for supporting the overall HR strategy and enhancing psychological contracts, which in turn are beneficial both for the firm and for its employees (McDermott, Conway, Rousseau and Flood, 2013). To date, the literature on HR practices has evolved separately from that on distributed leadership, with little synergy between the two. Acquirer leadership (Bass, 1985, Pawar and Eastman, 1997, Conger and Kanungo, 1998, Waldman and Yammarino, 1999, Judge and Piccolo, 2004, Nemanich and Keller, 2007, Sosik and Dinger, 2007) can moderate the effect of formalized HR practices on organizational ambidexterity in the post-acquisition period (Kaplan and Kaiser, 2003, Hirak, Peng, Carmeli and Schaubroeck, 2012).

Although the reaction of employees of the target firm to EMNE management style is crucial for the success of EMNE M\&As, few studies have examined the effect of EMNE M\&As on employees of the subsidiaries (Rao-Nicholson et al., 2015). Studies have shown that human issues, such as employee indifference toward the acquirer, especially in the case of EMNEs, can lead to failure of the M\&A transaction (Cartwright and Cooper, 1993, Larsson and Finkelstein, 1999, Larsson and Lubatkin, 2001, Gomes et al., 2011, Stahl et al., 2013). It is, therefore, important to examine the formalized HR practices and leadership style adopted by EMNEs in cross-border M\&As, and their effect on organizational ambidexterity. 
It has been suggested in the literature that organizational ambidexterity plays a key role in improving firm performance (Raisch, Birkinshaw, Probst and Tushman, 2009, Turner, Swart and Maylor, 2013). Among the challenges that arise in aligning the strategy of the firm with its resources and capabilities in a way that can lead to organizational ambidexterity and ensuing performance gains (Raisch and Birkinshaw, 2008), some of the most important are HR practices (McClean and Collins, 2011, Prieto and Pilar Pérez Santana, 2012) and leadership (Nemanich and Vera, 2009, Mom, Fourné and Jansen, 2015, Yitzhack Halevi, Carmeli and Brueller, 2015).

The literature on HR practices has focused on employment security, performancebased compensation, hiring, job-related training, sharing of corporate information, reduction of status differences, and decentralization (Pfeffer and Veiga, 1999, Bloom, Genakos, Sadun and Van Reenen, 2012), in other words, the typical formalized aspect of HR practices. Appropriately developed formalized HR practices can nurture employee commitment, limit turnover, and boost the productivity of the firm and its employees, leading to organizational ambidexterity (Huselid, 1995, Jiang, Lepak, Hu and Baer, 2012, Kehoe and Wright, 2013). Differences between these HR systems across countries also affect operating effectiveness of the companies, including ambidexterity (Jiang, Colakoglu, Lepak, Blasi and Kruse, 2014).

The acquirers' HR practices can affect their organizational ambidexterity. For example, the way in which employees of the target firm perceive the acquirer is driven to a large extent by the acquirers' formalized HR practices and by how the employees of the target feel after the M\&A. Thus, the organizational ambidexterity of the acquirer can have considerable influence on the way in which employees of the target firm perceive the M\&A in the long term (Nemanich and Vera, 2009, O'Reilly and Tushman, 2013, Meglio, King and Risberg, 2015). 
Despite the contributions of HR practices and the role of distributed leadership in organizations, research on M\&As has not integrated the influence of HR practices on organizational ambidexterity and the contingent role of distributed leadership. The combination of the two is rare in the context of the EMNEs (Gunkel, Schlaegel, Rossteutscher and Wolff, 2015, Rao-Nicholson et al., 2015). Above all, we lack multilevel models that combine the role of HR practices in organizational ambidexterity and show how distributed leadership, as a contingency variable, influences such outcomes, as a result of differences in institutional and cultural factors, especially in a cross-border context. Similarly, recent meta-analytic studies that explored the role of HRM practices in organizational outcomes have found a large portion of unexplained variance, highlighting the need for more fine-grained investigation of the contingency variables (Combs, Liu, Hall and Ketchen, 2006, Jiang et al., 2012).

Thus, the main objective of the present article is to examine (a) the effect of formalized EMNE HR practices on organizational ambidexterity and (b) the contingency effect of the distributed leadership on this relationship, in the context of cross-border M\&As undertaken by EMNEs (Kaplan and Kaiser, 2003, Nemanich and Vera, 2009, Hirak et al., 2012, O'Reilly and Tushman, 2013, Meglio et al., 2015). The study aims to answer the following important questions: Do formalized HR practices in EMNE subsidiaries affect their organizational ambidexterity? Does distributed EMNE leadership affect the relationship between HR practices and organizational ambidexterity?

The article contributes to our understanding of organizational ambidexterity in crossborder M\&As in three important ways: (a) we extend the literature on organizational ambidexterity by testing a multilevel model for understanding the influence of various (formalized) HRM practices on organizatioal ambidexterity in the context of cross-border EMNE M\&As; (b) we examine the contingent effect of distributed leadership on such 
outcome, bringing this important concept within the mainstream of M\&A research; and (c) we explore cross-border M\&As undertaken by five key EMNEs (Brazil, Russia, India, China, and South Africa), providing a fine-grained understanding of their overseas-acquired subsidiaries' organizational ambidexterity (bearing in mind that most research on this topic concerns the developed economies).

\section{Literature Review and Hypotheses}

HR practices and Organizational Ambidexterity

Research has shown that firms that do well in cross-border transactions are those that adopt flexible HR practices and policies in foreign locations (Stroh and Caligiuri, 1998). Examination of 60 of the world's top multinational organizations shows that effective people management in global activities helps companies improve their financial performance. Thus, HR-related activities (Prieto and Pilar Pérez Santana, 2012) that help organizations gain a competitive advantage on a global scale are important, especially for EMNEs with limited global exposure.

Junni, Sarala, Taras and Tarba (2013) and Junni, Sarala, Tarba, Liu and Cooper (2015) noted that it is important to explore the phenomenon of ambidexterity beyond the organizational level, and recommended using the macro-level approach as one of potentially promising ways of advancing future ambidexterity research. But to date there has been scarce research on ambidexterity at the individual level of analysis (Turner et al., 2013). For example, Filippini, Güttel and Nosella (2012), exploring ambidextrous routines in knowledge management, found that specific initiatives may facilitate concurrent exploration and exploitation at the micro-level. In the same vein, Huang and Kim (2013), studying LG Electronics, concluded that it achieved structural ambidexterity in human resource 
management (HRM) through architectural innovation, and underlined the importance of continually adjusting HRM practices to changes in the volatile business environment.

Chang (2015) found that firm-level employee human capital partially mediates the relationship between firm-level HR practices and organizational ambidexterity. Kostopoulos, Bozionelos and Syrigos (2015) presented a cross-level model exploring the influence of intellectual capital facets (i.e., human, social, and organizational capital) on unit ambidexterity, and suggested that organizational-level high-performance HR practices have a significant effect on the aforementioned factors as well as on the relationship between unit ambidexterity and unit performance. These findings show that the relationship between ambidexterity and unit performance becomes more salient in organizations with enhanced HR practices (Kostopoulos et al., 2015).

A recent study by Ahammad, Lee, Malul and Shoham (2015) examined the effect of motivation-enhancing HR practices on the productivity, motivation, and performance of commercial bank employees in promoting and attaining contextual ambidexterity within the organization, and showed how ex ante incentives (based on past performance) and ex post incentives (based on future performance) affect the productivity, motivation, and performance of employees. The authors found that workers with relatively high abilities may take advantage of both ex ante and ex post incentives, but in stark contrast to their colleagues, workers with relatively low ability were unable to take advantage of either scheme (Ahammad et al., 2015).

\section{HR Practices and Ambidexterity in M\&As}

As Stettner and Lavie (2014) have shown, prior research on ambidexterity has limited its concern to the interplay between tendencies to explore vs. exploit based on particular modes of operation (internal organization, alliances, and acquisitions), but balancing these tendencies within each mode undermines firm performance because of conflicting routines, 
negative transfer, and limited specialization. The authors have argued that by exploring in one mode and exploiting in another, i.e., balancing across modes, a firm can avoid some of these impediments. Based on the analysis of 190 US-based software firms, they have shown that exploration by externally oriented means such as acquisitions or alliances, and at the same time exploitation through internal organization, improves the performance of these firms.

It is critical to distinguish between formalized practices developed to enhance employee performance, in which procedures are designed and well-engrained in the target organization (Williams and Lee, 2016), and other informal practices that can probably affect organizational ambidexterity in the post-acquisition period (Björkman, Stahl and Vaara, 2007, Chakrabarti, Gupta-Mukherjee and Jayaraman, 2009, Zhu, Wang, Zheng, Liu and Miao, 2013). Formalized HR practices are essential for reducing inefficiencies in the acquired organization (Morris, Snell and Wright, 2006). EMNEs can use codified, formal procedures and systems to reduce inefficiencies in their foreign M\&As. Acquirers can also develop employee skills and abilities using effective HR systems (Barton and Delbridge, 2004). Formally designed and developed HR practices can be applied in several areas such as appraisals, rewards, and job design (Guest, 1997).

But differences between these HR systems across countries have implications for the operating effectiveness of the companies. Jiang et al. (2014) explored the relationship between the involvement of work systems and operational effectiveness, controlling for the effect of organizational climate of participation and national cultural differences in power distance. Their results indicate that the mediated relationship between the involvement of work systems and operational effectiveness in the context of climate of participation was stronger in facilities in lower power distance societies, while the direct relationship between the involvement of work systems and operational effectiveness was stronger in higher power 
distance societies. Thus, EMNEs from typically high power distance countries must take into account local sensibilities and employee aspirations in the post-acquisition period, which could affect ambidexterity of their acquired subsidiaries.

Research suggests that ambidexterity is important for organizational survival and success (Tushman and O'Reilly, 1996). Organizational ambidexterity is defined as the ability of organizations to grow through exploration and exploitation (Nemanich and Vera, 2009). In an M\&A context, ambidextrous EMNEs have competences for generating synergies with the acquirer and target to produce prized future exploitative opportunities (Nemanich and Vera, 2009, Rao-Nicholson et al., 2015). Thus, a key area for EMNEs to focus on during the postacquisition phase is that of their HR practices, because effective HR practices can improve organizational ambidexterity (McClean and Collins, 2011, Prieto and Pilar Pérez Santana, 2012).

The systematic and well-organized approach of EMNEs toward HR can indicate to employees of the target firm the seriousness with which the EMNE approaches the positive integration of the target into the acquirer's organization. Formalization implies that procedures are in place to store prior knowledge and information that are conducive to organizational ambidexterity. Similarly, formalization of HR practices can remove barriers to knowledge exchange during the M\&A integration process because explicit procedures can deliver incentives to foster collaboration between employees of the target and the acquirer firms, and in general, work toward organizational ambidexterity (Patel, Messersmith and Lepak, 2013). Thus:

H1: Formalized HR practices adopted by EMNEs in their acquired subsidiaries have a positive relationship with their organizational ambidexterity.

The Moderating Role of Distributed Leadership as a Contingency 
The above discussion suggests that by adopting formalized HR practices, cross-border M\&As by EMNEs can improve their organizational ambidexterity. This is akin to the widely held view in the literature that by adopting best HR practices most firms can improve their performance (Huselid, 1995, McClean and Collins, 2011). In contrast to this approach, the contingency-based view suggests that the influence of such practices can be intensified or constrained by specific situation-related factors (Jackson and Schuler, 1995, Kim and Wright, 2011). To the best of our knowledge, no study has investigated the possible contingencies of the relationship between HR practices in cross-border acquisitions of subsidiaries and the organizational ambidexterity of the acquired subsidiaries. One such contingency factor could be a particular leadership style. Figure 1 shows the conceptual framework depicting the relationships between HR practices concerning organizational ambidexterity and the moderating role of distributed leadership Undeniably, the latter plays an important role in organizational survival and is pertinent to creating an ambidextrous organization (Jansen, Tempelaar, Van den Bosch and Volberda, 2009, Cao, Simsek and Zhang, 2010, Rosing, Frese and Bausch, 2011).

Distributed leadership can use different approaches to manage ambidexterity; for example, the task-oriented approach (Tushman and O'Reilly, 1996), can introduce flexibility and develop an ambidextrous organization (Jansen et al., 2009, Cao et al., 2010, Rosing et al., 2011). Distributed leadership is defined as a shared-goal driven, collaboration-centered method, which results in sharing of leadership across the organization or the group in a way that affects the achievement of common goals (Carson, Tesluk and Marrone, 2007, Thorpe et al., 2011). Although distributed leadership can affect the success of cross-border EMNE M\&As, there is scarce research on its effect on the links between formalized HR practices and organizational ambidexterity (Shimizu, Hitt, Vaidyanath and Pisano, 2004, Waldman and Javidan, 2009, Weber and Tarba, 2010, Junni and Sarala, 2014). Distributed leadership can 
be a valuable asset for EMNEs in leveraging the leadership of the acquired targets as they assimilate managerial practices and competences into their organizations.

Research has shown that distributed leadership can have a positive influence on the collective performance of employees in an inter-organizational context (Shamir and Lapidot, 2003, Carson et al., 2007, D'Innocenzo, Mathieu and Kukenberger, 2014, Wang, Waldman and Zhang, 2014). The underlying explanation of the advantage of distributed leadership is the understanding that it is difficult for one leader to possess the knowledge and skills required to provide oversight and direction to organizational activities (Pearce and Manz, 2005). This is especially true for EMNE managers and top management teams, because they might not have experience in managing companies in foreign locations.

EMNE leadership can also grant their targets greater flexibility and freedom to manage resilience and innovation in the face of uncertainty (Patterson, West, \& Wall, 2004). For example, distributed leadership may develop a task-oriented approach to personnel management. In the relationship between formalized HR practices and ambidexterity, the acquirer's distributed leadership creates better synergies in targets and improves the ability of the acquirer to cope with uncertainty during the M\&A process. Thus, acquirer's distributed leadership positively moderates the effect of HR practices on organizational ambidexterity. Hence:

H2: The greater the distributed leadership practiced by the EMNE within the acquired subsidiary, the stronger the effect of the formalized HR practices on the organizational ambidexterity of the acquired subsidiary. 


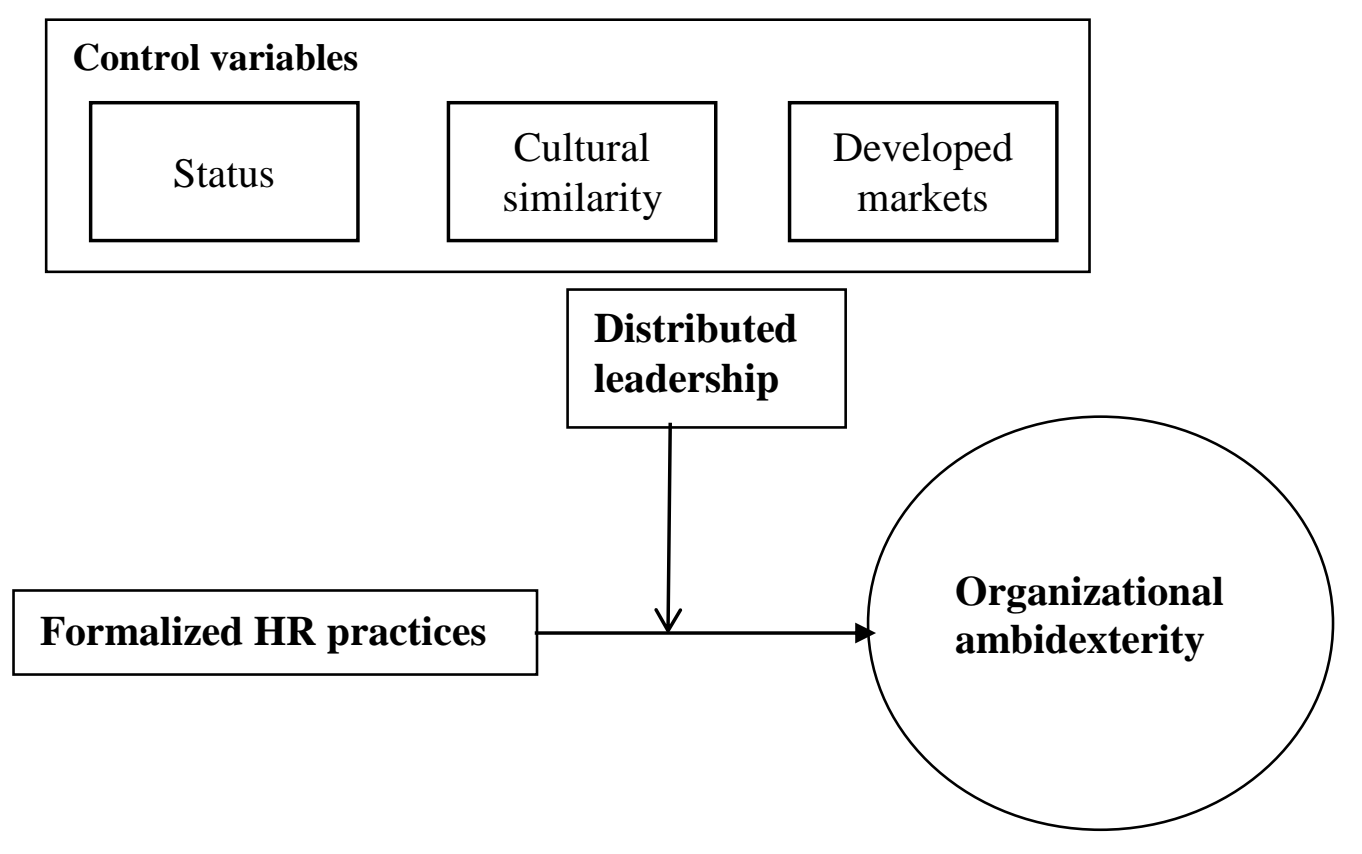

Figure 1. Conceptual model of subsidiary HR practices and distributed leadership on organizational ambidexterity 


\section{Data and Methods}

The methodology used in this study is similar to the one used by Larsson and Lubatkin (2001), Larsson and Finkelstein (1999), and Larsson (1993). A similar integrative research review methodology has been used by other authors, including Cooper (1984), Yin (1981), and Yin and Heald (1975). Cases were collected and sorted according to the previously established criteria that meet the research requirements (see Appendix A for further details). The cases were identified in a structured manner, and coding was used to convert qualitative into quantitative data. The data collected using this methodology were then used in the empirical analysis (Jauch, Osborn and Martin, 1980, Bullock and Tubbs, 1990, Larsson and Finkelstein, 1999).

This method is useful in situations in which experimental designs are difficult and time-consuming. The case survey method provides opportunities for generating larger sample sizes than those achievable by other techniques. As evidenced by the literature (Larsson and Finkelstein, 1999), this method is sufficiently robust and rigorous. The rich data on the cultural, social, and HR topics involved in M\&As can be obtained from case studies and media material (Larsson and Lubatkin, 2001), and key issues of procedural nature can be remedied by using multiple coders at the case analysis stage (Larsson and Finkelstein, 1999).

The present study considers cross-border M\&As from key emerging markets: Brazil, Russia, India, China, and South Africa (the so-called BRICs). Recent literature has provided detailed information on the motivations and means for internationalization of EMNEs (Boateng, Qian and Tianle, 2008, Zhang, Zhou and Ebbers, 2011, Kohli and Mann, 2012, Wang, Hong, Kafouros and Boateng, 2012, Huang and Renyong, 2014, Ning, Kuo, Strange and Wang, 2014). These five countries provide a good mix of domestic institutional context, cultural differences, and industries that engage in outward foreign direct investment (Hofstede, 1984, Buckley, Forsans and Munjal, 2012, Kohli and Mann, 2012, Wang et al., 
2012, Nicholson and Salaber, 2013, Contractor, Lahiri, Elango and Kundu, 2014, Nair, Demirbag and Mellahi, 2015).

Data on M\&As from these five countries were collected from the Thomson One database. Other studies on cross-border M\&As from these countries have used this database (Nicholson and Salaber, 2013, Rao-Nicholson et al., 2015). The information on acquirers and targets from this database concerned over 1,000 deals from these countries. The following databases and sources were used to collect information on the M\&As: Business Source Premier, JSTOR, HBR cases, and direct searches for cases using the Google search engine. Case material was also collected from newspaper articles, for example, in Fortune magazine, as has been done in the past in academic research (Larsson and Finkelstein, 1999). After screening for relevance, $84 \mathrm{M} \&$ As were included in this study. The deals included 14 by Indian acquirers, 15 by Chinese acquirers, 20 by Russian acquirers, 16 by Brazilian acquirers, and 19 by South African acquirers. The material used to collect data consisted of case studies and newspaper articles that were 1-25 pages in length. The case material was required to provide information on the leadership of the target and the acquirer, organizational ambidexterity, and other information pertinent for the study. Most of the information used in the study was cross-referenced with data from various sources to maintain the robustness of data collection process.

Coding followed the method used by Larsson and Lubatkin (2001), Larsson and Finkelstein (1999), and Larsson (1993), and the measures used were similar to those used in these earlier studies. Each variable was scored on a 6-point scale, and the quality constraint was provided by inter-rater reliability. Three independent raters coded all the data used in the study. Prior studies have suggested that an intraclass correlation coefficient (ICC) of 0.70 can be considered satisfactory and an ICC above 0.80 as good (Larsson, 1993, Larsson and Finkelstein, 1999, Larsson and Lubatkin, 2001, Neuendorf, 2002, Stahl, Larsson, Kremershof 
and Sitkin, 2011). Appendix A provides details on all the indicators used in the empirical analysis. Table 1 shows the country-level differences in the location of deals, organizational ambidexterity, and leadership. Note that the targets of Indian, Brazilian, and South African companies demonstrate a higher level of organizational ambidexterity and a higher degree of distributed leadership than do those of Russia and China.

\section{[Insert Table 1 here]}

Table 1. Cross-border deals and relevant details by country

\begin{tabular}{|l|l|l|l|l|}
\hline Country & Total deals & Deals in & Organizational & Distributed \\
& & markets & ambidexterity & leadership \\
\hline India & 14 & 9 & 8 & 10 \\
\hline China & 15 & 10 & 5 & 3 \\
\hline Russia & 20 & 11 & 11 & 4 \\
\hline Brazil & 16 & 11 & 10 & 12 \\
\hline South Africa & 19 & 12 & 17 & 12 \\
\hline
\end{tabular}

Dependent variable: organizational ambidexterity, which measures the ambidexterity demonstrated by the acquirer company (values of one or zero).

Explanatory variable: formalized HR practices, which denotes the formalized HR practices implemented in the target companies during the post-acquisition period (values of one or zero). 
Moderating variable: distributed leadership, which indicates whether a distributed leadership approach on the part of the EMNEs can be detected in their cross-border M\&As (values of one or zero).

\section{Control variables:}

Lack of information during and after the takeover can create difficulties for EMNEs as well as for other acquirers (Appelbaum, et al., 2007a; Rottig, 2013). Employees of the target form national stereotypes because of limited understanding of the EMNEs and their management style (Appelbaum, et al., 2007b; Rottig, 2013; Rottig, et al., 2014). The country of origin of the target can affect M\&A performance. To capture these three effects in our model, we introduced three control variables: Status consisted of four items and was measured on a 6-point scale ranging from low $=0$ to high $=5$. This index measures deal responsiveness by employees based on deal characteristics (Cronbach's $\alpha=0.91$ ). Cultural similarity consisted of two items and was measured on a 6-point scale ranging from low $=0$ to high $=5$. This index measures the degree of similarity in management style between the two organizations involved in the acquisitions (Cronbach's $\alpha=0.94)$. Developed market is a dummy variable that takes a value of one if the target belonged to a developed country, as classified by the OECD, or of zero otherwise. The two control variables (status, cultural similarities) consisted of multiple items, which made it important to explore the quality of the variables and their measures. Exploratory factor analysis with varimax rotations, eigenvalues $\geq 1$, and scree plots helped refine them.

We also controlled for various deal-, firm-, and country-level effects. The effect of the distance of market-supporting institutions was captured using the economic freedom index developed by the Heritage Foundation (Kane, Holmes and O'Grady, 2007, Meyer, Estrin, Bhaumik and Peng, 2009). This measure provides information on a wide range of institutions, focusing on the freedom of individuals and firms in a country to pursue their business 
activities. We defined variable HIGHTECH $=1$ if the target belonged to the high-tech industry, otherwise 0 . We also controlled for the ownership effects of the target. We defined the variables BUSINESS_GROUP $=1$ if the acquirer was part of a business group, otherwise 0, and GOVERNMENT_OWNERSHIP $=1$ if the acquirer was owned by the home government, otherwise 0. We defined the variable $\mathrm{CASH}=1$ if the deal was paid for in cash, otherwise 0 . If there had been colonial links between countries or if the country had been part of Soviet bloc, we assigned the variable HISTORICAL_LINKS = 1, otherwise 0. Finally, we assigned the variable PRIVATE_ACQUIRER $=1$ if the acquirer was private, otherwise 0. The correlation matrix of the variable/construct is presented in Table 2. As expected based on prior literature (Larsson and Lubatkin, 2001), we observed a high correlation between some of these variables, but none of the correlations were high enough to suggest that multicollinearity was not an issue in our analysis.

[Insert Table 2 here] 
Table 2. Descriptive statistics and correlation matrix

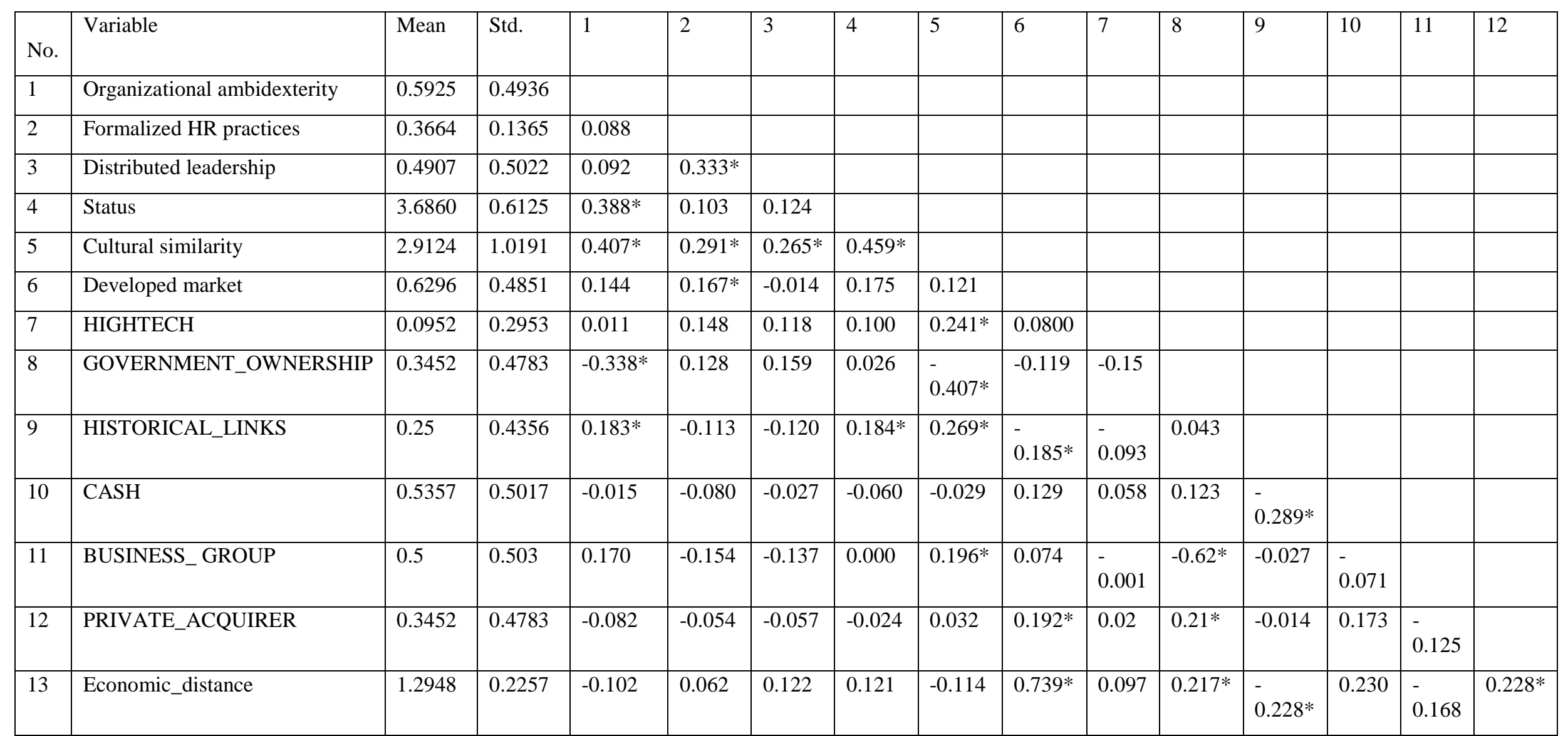

* Significance of correlation at $\mathrm{p}<0.1$. 


\section{Results}

Because our dependent variable takes binary values, we conducted the empirical analysis using the Probit regression model to test our two hypotheses. Table 3 reports the results of the Probit regression models, estimating the probability of organizational ambidexterity while formalized HR practices and distributed leadership are implemented in the target organization. Column (1) presents our baseline model with all control variables. Column (2) presents the results for our model with formalized HR practices alone. Note that our explanatory variable, formalized HR practices, is positive and significant (coeff $=0.00158$, $5 \%$ significance). Next, we introduced in our baseline model the moderating effect variable, distributed leadership $\mathrm{x}$ formalized HR practices, on its own and found that it had a positive and highly significant effect on organizational ambidexterity $($ coeff $=3.593,1 \%$ significance). Finally, we examined the effect of the moderating variable on our key explanatory variable and found that the effect of formalized HR practices on organizational ambidexterity was strengthened in the final model (coeff $=0.002,10 \%$ significance) when we considered the moderating effect of distributed leadership. These results support our hypotheses 1 and 2 that formalized HR practices positively affect organizational ambidexterity, and that this effect is further strengthened by distributed leadership.

Among our control variables, we observed that the status of the acquirer and cultural similarity between the acquirer and target organizations had a positive effect on organizational ambidexterity, indicating that target employees' perceptions of the deal and similarity in management styles can positively contribute to organizational ambidexterity. Research has shown that employees displayed negative reactions to mergers because of the uncertainty involved in such transactions, but that if their perception of the deal was positive, they invested effort and contributed to organizational ambidexterity. We also found that business-group membership had a positive effect on organizational ambidexterity in our full 
model (Column (4)). Private ownership of the acquirer had a negative effect on organizational ambidexterity. Finally, Indian and Brazilian acquisitions demonstrate limited organizational ambidexterity compared with acquisitions by other BRICS countries.

Table 3. Results of the Probit regressions

\begin{tabular}{|c|c|c|c|c|}
\hline VARIABLES & (1) & (2) & (3) & (4) \\
\hline Formalized HR practices & & $\begin{array}{l}0.00158 * * \\
(0.000692)\end{array}$ & & $\begin{array}{l}0.00201 * \\
(0.00100)\end{array}$ \\
\hline Distributed leadership X & & & $3.593 * * *$ & $4.173 * * *$ \\
\hline Formalized HR practices & & & $(0.942)$ & (1.128) \\
\hline Status & $\begin{array}{c}1.600 * * * \\
(0.504)\end{array}$ & $\begin{array}{l}2.103 * * * \\
(0.700)\end{array}$ & $\begin{array}{c}2.702 * * * \\
(0.779)\end{array}$ & $\begin{array}{c}3.006 * * * \\
(1.045)\end{array}$ \\
\hline Cultural similarity & $\begin{array}{c}1.126^{* * * *} \\
(0.385)\end{array}$ & $\begin{array}{c}1.108 * * * \\
(0.400)\end{array}$ & $\begin{array}{c}1.650 * * * \\
(0.419)\end{array}$ & $\begin{array}{c}1.945 * * * \\
(0.541)\end{array}$ \\
\hline Developed market & $\begin{array}{c}1.818 \\
(1.111)\end{array}$ & $\begin{array}{c}1.903 \\
(1.262)\end{array}$ & $\begin{array}{c}1.300 \\
(1.205)\end{array}$ & $\begin{array}{c}1.825 \\
(1.275)\end{array}$ \\
\hline HIGHTECH & $\begin{array}{l}-0.930 \\
(0.694)\end{array}$ & $\begin{array}{l}-0.818 \\
(0.770)\end{array}$ & $\begin{array}{c}-2.553^{* *} \\
(1.078)\end{array}$ & $\begin{array}{l}-1.828 \\
(1.439)\end{array}$ \\
\hline $\begin{array}{l}\text { GOVERNMENT_ } \\
\text { OWNERSHIP }\end{array}$ & $-1.903 * * *$ & $-3.278 * * *$ & -1.045 & -2.888 \\
\hline & $(0.689)$ & $(1.161)$ & $(0.730)$ & $(1.783)$ \\
\hline HISTORICAL_LINKS & $\begin{array}{c}0.235 \\
(0.775)\end{array}$ & $\begin{array}{c}1.436 \\
(0.969)\end{array}$ & $\begin{array}{l}-0.497 \\
(0.834)\end{array}$ & $\begin{array}{c}0.934 \\
(1.355)\end{array}$ \\
\hline CASH & $\begin{array}{c}0.150 \\
(0.522)\end{array}$ & $\begin{array}{c}0.401 \\
(0.536)\end{array}$ & $\begin{array}{l}-0.373 \\
(0.625)\end{array}$ & $\begin{array}{l}-0.0745 \\
(0.717)\end{array}$ \\
\hline BUSINESS_GROUP & $\begin{array}{c}0.540 \\
(0.517)\end{array}$ & $\begin{array}{c}0.893 \\
(0.609)\end{array}$ & $\begin{array}{c}1.406 \\
(0.942)\end{array}$ & $\begin{array}{l}1.942^{*} \\
(1.162)\end{array}$ \\
\hline PRIVATE_ACQUIRER & $\begin{array}{l}-1.070 * * \\
(0.543)\end{array}$ & $\begin{array}{c}-1.339 * * \\
(0.558)\end{array}$ & $\begin{array}{c}-1.622 * * \\
(0.799)\end{array}$ & $\begin{array}{c}-2.825 * * * \\
(0.823)\end{array}$ \\
\hline Economic distance & $\begin{array}{l}-1.127 \\
(2.831)\end{array}$ & $\begin{array}{c}0.231 \\
(3.056)\end{array}$ & $\begin{array}{l}-0.559 \\
(3.125)\end{array}$ & $\begin{array}{l}-0.337 \\
(3.376)\end{array}$ \\
\hline Sector dummies & Included & Included & Included & Included \\
\hline Dummy (India) & $\begin{array}{c}-2.825 * * \\
(1.107)\end{array}$ & $\begin{array}{c}-4.023 * * * \\
(1.471)\end{array}$ & $\begin{array}{l}-4.602 * * * \\
(1.205)\end{array}$ & $\begin{array}{c}-5.765^{* * *} \\
(1.805)\end{array}$ \\
\hline Dummy (China) & $\begin{array}{l}-0.492 \\
(0.979)\end{array}$ & $\begin{array}{l}-0.759 \\
(1.199)\end{array}$ & $\begin{array}{l}-1.542 \\
(0.950)\end{array}$ & $\begin{array}{l}-0.549 \\
(1.688)\end{array}$ \\
\hline Dummy (Russia) & $\begin{array}{l}1.963 * \\
(1.153)\end{array}$ & $\begin{array}{l}1.968 \\
(1.431)\end{array}$ & $\begin{array}{c}1.842 \\
(1.121)\end{array}$ & $\begin{array}{l}4.323 \\
(2.664)\end{array}$ \\
\hline Dummy (Brazil) & $\begin{array}{l}-0.859 \\
(0.673)\end{array}$ & $\begin{array}{l}-1.739 * \\
(0.996)\end{array}$ & $\begin{array}{l}-1.608^{*} \\
(0.926)\end{array}$ & $\begin{array}{l}-2.027 * \\
(1.149)\end{array}$ \\
\hline Constant & $\begin{array}{c}-7.730 * * \\
(3.315)\end{array}$ & $\begin{array}{c}-10.37 * * * \\
(3.406)\end{array}$ & $\begin{array}{c}-14.21 * * * \\
(3.870)\end{array}$ & $\begin{array}{c}-17.17 * * * \\
(4.654)\end{array}$ \\
\hline Observations & 75 & 72 & 75 & 72 \\
\hline
\end{tabular}




\begin{tabular}{lllll} 
Prob > chi2 & 0.0003 & 0.0018 & 0.0001 & 0.0009 \\
Pseudo R2 & 0.5209 & 0.5815 & 0.6622 & 0.7356 \\
\hline
\end{tabular}

Robust standard errors in parentheses

$* * * \mathrm{p}<0.01, * * \mathrm{p}<0.05, * \mathrm{p}<0.1$

\section{Discussion and Conclusions}

The aim of the present article was to investigate the conditions that lead to organizational ambidexterity, especially in the context of cross-border mergers and acquisitions undertaken by firms from emerging economies. It has been suggested that organizational ambidexterity plays an important role in enhancing the performance of firms (Raisch and Birkinshaw, 2008, Raisch et al., 2009), but its potentially enabling antecedents are not well known, and existing studies often report conflicting results (Raisch and Birkinshaw, 2008). Recently, scholars have focused their attention on understanding the role of HR management practices on organizational ambidexterity (Prieto and Pilar Pérez Santana, 2012, Patel et al., 2013), while others have focused on top management team characteristics and their influence on organizational ambidexterity (Simsek, 2009). To date, both streams of literature (HR and leadership) have evolved separately, with little cross-fertilization.

Keeping in view the inconsistent and conflicting findings of previous research on the antecedents of organizational ambidexterity, in the present article we investigated specifically the role of HR practices on the organizational ambidexterity of subsidiaries acquired by EMNEs by developing a multilevel model, and integrated the contingency role of distributed leadership in enhancing the ambidexterity of the acquired subsidiaries. Previous research suggests that HR practices play an important role in improving organizational performance (Huselid, 1995), but research has also noted that there could be contingency factors that interact with HR practices, leading to different performance outcomes (Jackson and Schuler, 1995, Kim and Wright, 2011). We focused on one such potential contingency factor, 
distributed leadership, as one of the key moderators that interact with HR practices, leading to organizational ambidexterity in cross-border M\&As. Using the context of the emerging economies and cross-border M\&As involving 84 deals, we found that formalized HR practices have a positive effect in enhancing the organizational ambidexterity of EMNEacquired subsidiaries. These findings support those of recent studies indicating that HR systems that assume the form of a high-performance work system can be an important antecedent of ambidexterity (Prieto and Pilar Pérez Santana, 2012, Patel et al., 2013).

In this article, we proposed and tested the potential contingency role of distributed leadership in enhancing the ambidexterity of acquired subsidiaries. To date, research on mergers and acquisitions has not integrated and theorized the potentially moderating effect of this important concept on post-acquisition performance, including ambidexterity. Our results suggest and support the proposed contingency role of distributed leadership in interacting with HR practices that make possible the ambidexterity of subsidiaries acquired by EMNEs. We found that the effect of HR practices becomes much stronger when we take into account the moderating role of distributed leadership, indicating the importance of the latter (Bolden, 2011, Thorpe et al., 2011) as a key variable that can explain variations in the ambidexterity of firms involved in cross-border M\&As.

\section{Theoretical Implications and Contributions}

This article provides important theoretical insights and makes three key contibutions, not only to the traditional HR literature, but also to the emerging international HR management literature, especially by examining the five BRICs economies and the ambidexterity of acquired subsidiaries. Furthermore, we integrated the HR, leadership, and ambidexterity literatures, responding to the calls for combining different literature streams in order to understand organizational ambidexterity (Simsek, 2009). Although the important role of HR practices and leadership in organizations has been acknowledged before, most research 
conducted on M\&As has not combined the influence of HR practices and of particular leadership styles on organizational ambidexterity. The few studies that have investigated the role of leadership have focused primarily on traditional leadership styles, such as transformational and transactional (Nemanich and Keller, 2007, Vasilaki, 2011), a combination that is quite rare in the context of EMNEs (Sinkovics, Zagelmeyer and Kusstatscher, 2011, Gunkel et al., 2015, Rao-Nicholson et al., 2015). We also lack multilevel models that include the effect of HR practices on organizational ambidexterity, and describe how leadership, as a contingency variable, influences such outcomes, especially in the crossborder context, owing to differences in institutional and cultural factors.

This article expands our understanding of organizational ambidexterity in crossborder M\&As, especially those undertaken in emerging economies, which are becoming important actors in the global economy, in three ways: (a) we extended the literature on organizational ambidexterity by testing a multilevel model for understanding the influence of various (formalized) HRM practices on organizatioal ambidexterity in the context of crossborder M\&As by EMNEs; (b) we investigated the contingency role of distributed leadership in interacting with HRM practices, enhancing the ambidexterity of the acquired firms, which brings this important concept into the mainstream of M\&As research; (c) we examined crossborder M\&As undertaken by the five BRICs EMNEs, providing a fine-grained view of the organizational ambidexterity of their overseas acquired subsidiaries, bearing in mind that most research to date has been conducted in the context of developed economies.

\section{Managerial Implications}

The article has some important implications for practitioners. First, the findings indicate that formalized HR practices influence organizational ambidexterity, therefore, managers need to pay attention to employee training and selection, and establish HR systems conducive to ambidexterity. Second, the findings highlight the important role of distributed leadership. 
Therefore, firms should carefully select top managers who is going to emphasize shared leadership rather than confining it to the top level. Distributed leadership advances employees welfare and distributes decision-making processes to the lower levels, enhancing workers' engagement and productivity, which in turn leads to organizational ambidexterity.

\section{Limitations and Future Research Directions}

The present article has some limitations that future research must address. First, we investigated EMNEs from five large emerging economies; future studies should also include firms from other emerging economies such as Turkey, the UAE, Iran, and other emerging economies in Africa, which are under-represented in the mainstream business and management research. Second, we used the case survey method, which has potential benefits as well as weaknesses; future studies could build on these findings and conduct a large-scale survey or apply mixed methods. Longitudinal studies should also be conducted to explore the long-term effects of leadership and HR practices on the ambidexterity and performance of acquired firms. Third Lastly, it would be important to test other potential mediating and moderating variables, such as cultural distance and knowledge management practices, and their influence on the ambidexterity of acquired firms. 


\section{Appendix A. Case Survey Coding}

\section{Dependent Variable: Organizational ambidexterity}

Organizational ambidexterity examines how the acquirer manages the post-acquisition integration process. In the context of this work, this variable is related to the organizational ambidexterity in the host market, and assesses exploration and exploitation of resources in the situation of the target organization. The information was collected from the case material and the media. The variable takes a value of one if the acquirer demonstrates organizational ambidexterity in its style, otherwise it takes a zero.

\section{Independent Variable: Formalized HR practices}

This variable contains three elements that make up the formalized HR practices. The first one is a dummy variable. If the acquirer establishes, adopts, and maintains formalized HR practices in the target company during the post-acquisition period, it takes a value of one, otherwise it takes a value of zero. Formalized HR practices refer to processes and systems that are present or adopted at the target company, including formal rules for HR activities like hiring, promotion, recruitment, and redundancy. The second variable measures the level of uncertainty in the host country and whether the HR practices are designed to match this uncertainty. The variable takes a value of one if we observe such systems in place in the target organization during the post-acquisition period, otherwise it takes a value of zero. Finally, we examined whether the HR systems of the target firms are formally linked to manage the level of long-term orientation of the host country. The average of these three elements produced the level of formalized HR practices within a target organization.

\section{Moderating variable: Distributed leadership}

This variable measures whether we observe a distributed leadership approach by the EMNE in its cross-border M\&A. If the EMNE leadership allows the leadership of the target firm to 
collaboratively manage the operations in the host country during the post-acquisition period, the variable takes a value of one, otherwise a value of zero.

\section{Control variables}

Status (four items, each scored on a 6-point scale ranging from low $=0$ to high $=5$ )

- Takeover friendliness. Estimates the takeover friendliness between the target and the acquirer and is obtained from press releases.

- Power differential between the target and the acquirer. Estimates the power imbalance between the target and the acquirer. Relates to the perceived power of the target, compared with the power of the acquirer, as derived from discussions in the media.

- Relative firm size. Estimates the relative firm size, measured as number of employees, obtained from the annual reports of the firms in the year preceding the acquisition.

- Relative firm performance. Estimates relative firm performance, measured as net income, obtained from the annual reports of the acquirer and target firms in the year preceding the acquisition.

Cultural similarity (two items, each scored on a 6-point scale ranging from low $=0$ to high $=$

5)

- Shared meaning of the management and business process. If both countries had similar business environments, the companies are likely to experience synergies from cultural commonness. Estimates the degree of shared meaning between the firms.

- Management style similarity. Estimates the degree of management style similarity between the two companies involved in the acquisition process. The management style is assessed in relations to degrees (low vs. high) of formality, employee involvement, and any other factors underscored by the case author.

Developed market $($ Developed market $=1$ if an OECD country, otherwise 0 ).

Identifies the nationality of the target firm and whether or not it is an OECD country. 


\section{References}

Ahammad, M.F., Lee, M.S., Malul, M. and Shoham, A. (2015), "Behavioral Ambidexterity: The Impact of Incentive Schemes on Productivity, Motivation, and Performance of Employees in Commercial Banks," Human Resource Management, 54, 45-62.

Aybar, B. and Ficici, A. (2009), "Cross-border acquisitions and firm value: An analysis of emergingmarket multinationals," Journal of International Business Studies, 40, 1317-1338.

Barton, H. and Delbridge, R. (2004), "HRM in support of the learning factory: Evidence from the US and UK automotive components industries," The International Journal of Human Resource Management, 15, 331-345.

Bass, B.M. (1985), Leadership and performance beyond expectations, New York, NY: Free Press. Björkman, I., Stahl, G.K. and Vaara, E. (2007), "Cultural differences and capability transfer in crossborder acquisitions: The mediating roles of capability complementarity, absorptive capacity, and social integration," Journal of International Business Studies, 38, 658-672.

Bloom, N., Genakos, C., Sadun, R. and Van Reenen, J. (2012), "Management practices across firms and countries," The Academy of Management Perspectives, 26, 12-33.

Boateng, A., Qian, W. and Tianle, Y. (2008), "Cross-border M\&As by Chinese firms: An analysis of strategic motives and performance," Thunderbird international business review, 50, 259-270.

Bolden, R. (2011), "Distributed leadership in organizations: A review of theory and research," International Journal of Management Reviews, 13, 251-269.

Buckley, P.J., Forsans, N. and Munjal, S. (2012), "Host-home country linkages and host-home country specific advantages as determinants of foreign acquisitions by Indian firms," International Business Review, 21, 878-890.

Bullock, R. and Tubbs, M.E. (1990), "A case meta-analysis of gainsharing plans as organization development interventions," The journal of applied behavioral science, 26, 383-404.

Cao, Q., Simsek, Z. and Zhang, H. (2010), "Modelling the joint impact of the CEO and the TMT on organizational ambidexterity," Journal of Management Studies, 47, 1272-1296.

Carson, J.B., Tesluk, P.E. and Marrone, J.A. (2007), "Shared leadership in teams: An investigation of antecedent conditions and performance," Academy of Management Journal, 50, 1217-1234.

Cartwright, S. and Cooper, C.L. (1993), "The role of culture compatibility in successful organizational marriage," The Academy of Management Executive, 7, 57-70.

Chakrabarti, R., Gupta-Mukherjee, S. and Jayaraman, N. (2009), "Mars-Venus marriages: Culture and cross-border M\&A," Journal of International Business Studies, 40, 216-236.

Chang, Y.Y. (2015), "A multilevel examination of high-performance work systems and unit-level organisational ambidexterity," Human Resource Management Journal, 25, 79-101.

Combs, J., Liu, Y., Hall, A. and Ketchen, D. (2006), "HOW MUCH DO HIGH-PERFORMANCE WORK PRACTICES MATTER? A META-ANALYSIS OF THEIR EFFECTS ON ORGANIZATIONAL PERFORMANCE," Personnel Psychology, 59, 501-528.

Conger, J.A. and Kanungo, R.N. (1998), Charismatic leadership in organizations: Sage Publications. Contractor, F.J., Lahiri, S., Elango, B. and Kundu, S.K. (2014), "Institutional, cultural and industry related determinants of ownership choices in emerging market FDI acquisitions," International Business Review, 23, 931-941.

Cooper, H. (1984), "The integrative research review: A social science approach," Beverly Hills: Sage. D'Innocenzo, L., Mathieu, J.E. and Kukenberger, M.R. (2014), "A meta-analysis of different forms of shared leadership-team performance relations," Journal of Management, 0149206314525205.

Filippini, R., Güttel, W.H. and Nosella, A. (2012), "Ambidexterity and the evolution of knowledge management initiatives," Journal of Business Research, 65, 317-324.

Gomes, E., Angwin, D.N., Weber, Y. and Tarba, S.Y. (2013), "Critical success factors through the mergers and acquisitions process: revealing pre-and post-M\&A connections for improved performance," Thunderbird International Business Review, 55, 13-35. 
Gomes, E., Weber, Y., Brown, C. and Tarba, S.Y. (2011), Mergers, acquisitions and strategic alliances: Understanding the process: Palgrave Macmillan.

Gubbi, S., Aulakh, P., Ray, S., Sarkar, M. and Chittoor, R. (2010), "Do international acquisitions by emerging-economy firms create shareholder value: The case of Indian firms," Journal of International Business Studies, 41, 397-418.

Guest, D.E. (1997), "Human resource management and performance: a review and research agenda," The International Journal of Human Resource Management, 8, 263-276.

Gunkel, M., Schlaegel, C., Rossteutscher, T. and Wolff, B. (2015), "The human aspect of cross-border acquisition outcomes: The role of management practices, employee emotions, and national culture," International Business Review, 24, 394-408.

Haleblian, J., Devers, C.E., McNamara, G., Carpenter, M.A. and Davison, R.B. (2009), "Taking stock of what we know about mergers and acquisitions: A review and research agenda," Journal of Management, 35, 469-502.

Hattari, R. and Rajan, R.S. (2010), "India as a source of outward foreign direct investment," Oxford Development Studies, 38, 497-518.

Hirak, R., Peng, A.C., Carmeli, A. and Schaubroeck, J.M. (2012), "Linking leader inclusiveness to work unit performance: The importance of psychological safety and learning from failures," The Leadership Quarterly, 23, 107-117.

Hofstede, G. (1984), Culture's consequences: International differences in work-related values: sage. Huang, J. and Kim, H.J. (2013), "Conceptualizing structural ambidexterity into the innovation of human resource management architecture: The case of LG Electronics," The International Journal of Human Resource Management, 24, 922-943.

Huang, X. and Renyong, C. (2014), "Chinese Private Firms' Outward Foreign Direct Investment: Does Firm Ownership and Size Matter?," Thunderbird international business review, 56, 393-406.

Huang, Y. and Khanna, T. (2003), "Can India overtake china?," Foreign Policy, 137, 74-81.

Huselid, M.A. (1995), "The impact of human resource management practices on turnover, productivity, and corporate financial performance," Academy of Management Journal, 38, 635-672. Jackson, S.E. and Schuler, R.S. (1995), "Understanding human resource management in the context of organizations and their environments," Strategic Human Resource Management, 46, 237-264. Jansen, J.J., Tempelaar, M.P., Van den Bosch, F.A. and Volberda, H.W. (2009), "Structural differentiation and ambidexterity: The mediating role of integration mechanisms," Organization science, 20, 797-811.

Jauch, L.R., Osborn, R.N. and Martin, T.N. (1980), "Structured content analysis of cases: A complementary method for organizational research," Academy of management review, 5, 517-525. Jiang, K., Lepak, D.P., Hu, J. and Baer, J.C. (2012), "How does human resource management influence organizational outcomes? A meta-analytic investigation of mediating mechanisms," Academy of Management Journal, 55, 1264-1294.

Jiang, Y., Colakoglu, S., Lepak, D.P., Blasi, J.R. and Kruse, D.L. (2014), "Involvement work systems and operational effectiveness: Exploring the moderating effect of national power distance," Journal of International Business Studies, 46, 332-354.

Judge, T.A. and Piccolo, R.F. (2004), "Transformational and transactional leadership: a meta-analytic test of their relative validity," Journal of applied psychology, 89, 755.

Junni, P. and Sarala, R.M. (2014), "The role of leadership in mergers and acquisitions: A review of recent empirical studies," Advances in mergers and acquisitions, 13, 181-200.

Junni, P., Sarala, R.M., Taras, V. and Tarba, S.Y. (2013), "Organizational ambidexterity and performance: A meta-analysis," The Academy of Management Perspectives, 27, 299-312.

Junni, P., Sarala, R.M., Tarba, S.Y., Liu, Y. and Cooper, C.L. (2015), "Guest editors' introduction: The role of human resources and organizational factors in ambidexterity," Human Resource Management, 54, 1-28.

Kane, T., Holmes, K.R. and O'Grady, M.A. (2007), "2007 Index of economic freedom." 
Kaplan, R.E. and Kaiser, R.B. (2003), "Developing versatile leadership," MIT Sloan Management Review, 44, 19-26.

Kehoe, R.R. and Wright, P.M. (2013), "The impact of high-performance human resource practices on employees' attitudes and behaviors," Journal of management, 39, 366-391.

Kim, S. and Wright, P.M. (2011), "Putting strategic human resource management in context: A contextualized model of high commitment work systems and its implications in China," Management and organization review, 7, 153-174.

Kohli, R. and Mann, B.J.S. (2012), "Analyzing determinants of value creation in domestic and cross border acquisitions in India," International Business Review, 21, 998-1016.

Kostopoulos, K.C., Bozionelos, N. and Syrigos, E. (2015), "Ambidexterity and Unit Performance: Intellectual Capital Antecedents and Cross-Level Moderating Effects of Human Resource Practices," Human Resource Management, 54, 111-132.

Kumar, N. (2008), "Internationalization of Indian Enterprises: Patterns, Strategies, Ownership Advantages, and Implications," Asian Economic Policy Review, 3, 242-261.

Larsson, R. (1993), "Case survey methodology: Quantitative analysis of patterns across case studies," Academy of Management Journal, 36, 1515-1546.

Larsson, R. and Finkelstein, S. (1999), "Integrating strategic, organizational, and human resource perspectives on mergers and acquisitions: A case survey of synergy realization," Organization Science, 10, 1-26.

Larsson, R. and Lubatkin, M. (2001), "Achieving acculturation in mergers and acquisitions: An international case survey," Human relations, 54, 1573-1607.

Luo, Y. and Tung, R.L. (2007), "International expansion of emerging market enterprises: A springboard perspective," Journal of International Business Studies, 38, 481-498.

McClean, E. and Collins, C.J. (2011), "High-commitment HR practices, employee effort, and firm performance: Investigating the effects of HR practices across employee groups within professional services firms," Human Resource Management, 50, 341-363.

McDermott, A.M., Conway, E., Rousseau, D.M. and Flood, P.C. (2013), "Promoting effective psychological contracts through leadership: The missing link between HR strategy and performance," Human Resource Management, 52, 289-310.

Meglio, O., King, D.R. and Risberg, A. (2015), "Improving Acquisition Outcomes with Contextual Ambidexterity," Human Resource Management.

Meyer, K.E., Estrin, S., Bhaumik, S.K. and Peng, M.W. (2009), "Institutions, resources, and entry strategies in emerging economies," Strategic Management Journal, 30, 61-80.

Mom, T.J., Fourné, S.P. and Jansen, J.J. (2015), "Managers' work experience, ambidexterity, and performance: The contingency role of the work context," Human Resource Management, 54, 133153.

Morris, S.S., Snell, S.A. and Wright, P.M. (2006), "A resource-based view of international human resources: Toward a framework of integrative and creative capabilities," Handbook of research in international human resource management, 433-448.

Nair, S.R., Demirbag, M. and Mellahi, K. (2015), "Reverse knowledge transfer in emerging market multinationals: The Indian context," International Business Review.

Nemanich, L.A. and Keller, R.T. (2007), "Transformational leadership in an acquisition: A field study of employees," The Leadership Quarterly, 18, 49-68.

Nemanich, L.A. and Vera, D. (2009), "Transformational leadership and ambidexterity in the context of an acquisition," The Leadership Quarterly, 20, 19-33.

Neuendorf, K.A. (2002), The content analysis guidebook: Sage.

Nicholson, R.R. and Salaber, J. (2013), "The motives and performance of cross-border acquirers from emerging economies: Comparison between Chinese and Indian firms," International Business Review, 22, 963-980.

Ning, L., Kuo, J.-M., Strange, R. and Wang, B. (2014), "International investors' reactions to crossborder acquisitions by emerging market multinationals," International Business Review, 23, 811-823. 
O'Reilly, C.A. and Tushman, M.L. (2013), "Organizational ambidexterity: Past, present, and future," The Academy of Management Perspectives, 27, 324-338.

Patel, P.C., Messersmith, J.G. and Lepak, D.P. (2013), "Walking the tightrope: An assessment of the relationship between high-performance work systems and organizational ambidexterity," Academy of Management Journal, 56, 1420-1442.

Pawar, B.S. and Eastman, K.K. (1997), "The nature and implications of contextual influences on transformational leadership: A conceptual examination," Academy of Management Review, 22, 80109.

Pearce, C.L. and Manz, C.C. (2005), "The new silver bullets of leadership: The importance of self-and shared leadership in knowledge work," Organizational dynamics, 34, 130-140.

Pfeffer, J. and Veiga, J.F. (1999), "Putting people first for organizational success," The Academy of Management Executive, 13, 37-48.

Prieto, I.M. and Pilar Pérez Santana, M. (2012), "Building ambidexterity: The role of human resource practices in the performance of firms from Spain," Human Resource Management, 51, 189-211. Purushothaman, R. (2004), India: Realizing BRICs Potential: Goldman Sachs.

Raisch, S. and Birkinshaw, J. (2008), "Organizational Ambidexterity: Antecedents, Outcomes, and Moderators," Journal of Management, 34, 375-409.

Raisch, S., Birkinshaw, J., Probst, G. and Tushman, M.L. (2009), "Organizational ambidexterity: Balancing exploitation and exploration for sustained performance," Organization Science, 20, 685695.

Rao-Nicholson, R., Khan, Z. and Stokes, P. (2015), "Making great minds think alike: Emerging market multinational firms' leadership effects on targets' employee psychological safety after cross-border mergers and acquisitions," International Business Review.

Rao-Nicholson, R. and Salaber, J. (2015), "Impact of the Financial Crisis on Cross-Border Mergers and Acquisitions and Concentration in the Global Banking Industry," Thunderbird international business review.

Rosing, K., Frese, M. and Bausch, A. (2011), "Explaining the heterogeneity of the leadershipinnovation relationship: Ambidextrous leadership," The Leadership Quarterly, 22, 956-974.

Shamir, B. and Lapidot, Y. (2003), "Shared leadership in the management of group boundaries," in Shared leadership: Reframing the hows and whys of leadership, ed. J.A.C. C.L. Pearce, Thousand Oaks, CA: Sage Publications, pp. 235-247.

Shimizu, K., Hitt, M.A., Vaidyanath, D. and Pisano, V. (2004), "Theoretical foundations of crossborder mergers and acquisitions: A review of current research and recommendations for the future," Journal of International Management, 10, 307-353.

Simsek, Z. (2009), "Organizational ambidexterity: Towards a multilevel understanding," Journal of Management Studies, 46, 597-624.

Sinkovics, R.R., Zagelmeyer, S. and Kusstatscher, V. (2011), "Between merger and syndrome: The intermediary role of emotions in four cross-border M\&amp;As," International Business Review, 20, 27-47.

Sosik, J.J. and Dinger, S.L. (2007), "Relationships between leadership style and vision content: The moderating role of need for social approval, self-monitoring, and need for social power," The Leadership Quarterly, 18, 134-153.

Spillane, J.P., Halverson, R. and Diamond, J.B. (2004), "Towards a theory of leadership practice: A distributed perspective," Journal of curriculum studies, 36, 3-34.

Stahl, G.K., Angwin, D.N., Very, P., Gomes, E., Weber, Y., Tarba, S.Y., Noorderhaven, N., Benyamini, H., Bouckenooghe, D. and Chreim, S. (2013), "Sociocultural integration in mergers and acquisitions: Unresolved paradoxes and directions for future research," Thunderbird International Business Review, 55, 333-356.

Stahl, G.K., Larsson, R., Kremershof, I. and Sitkin, S.B. (2011), "Trust dynamics in acquisitions: A case survey," Human Resource Management, 50, 575-603. 
Stettner, U. and Lavie, D. (2014), "Ambidexterity under scrutiny: Exploration and exploitation via internal organization, alliances, and acquisitions," Strategic management journal, 35, 1903-1929. Stroh, L.K. and Caligiuri, P.M. (1998), "Increasing global competitiveness through effective people management," Journal of World Business, 33, 1-16.

Thorpe, R., Gold, J. and Lawler, J. (2011), "Locating distributed leadership," International Journal of Management Reviews, 13, 239-250.

Turner, N., Swart, J. and Maylor, H. (2013), "Mechanisms for managing ambidexterity: a review and research agenda," International Journal of Management Reviews, 15, 317-332.

Tushman, M.L. and O'Reilly, C.A. (1996), "The ambidextrous organizations: Managing evolutionary and revolutionary change," California Management Review, 38, 8-30.

Vasilaki, A. (2011), "The relationship between transformational leadership and postacquisition performance," International Studies of Management \& Organization, 41, 42-58.

Waldman, D.A. and Javidan, M. (2009), "Alternative forms of charismatic leadership in the integration of mergers and acquisitions," The Leadership Quarterly, 20, 130-142.

Waldman, D.A. and Yammarino, F.J. (1999), "CEO charismatic leadership: Levels-of-management and levels-of-analysis effects," Academy of Management Review, 24, 266-285.

Wang, C., Hong, J., Kafouros, M. and Boateng, A. (2012), "What drives outward FDI of Chinese firms? Testing the explanatory power of three theoretical frameworks," International Business Review, 21, 425-438.

Wang, D., Waldman, D.A. and Zhang, Z. (2014), "A meta-analysis of shared leadership and team effectiveness," Journal of applied psychology, 99, 181-198.

Weber, Y. and Tarba, S.Y. (2010), "Human resource practices and performance of mergers and acquisitions in Israel," Human resource Management review, 20, 203-211.

Weber, Y., Tarba, S.Y. and Reichel, A. (2011), "A model of the influence of culture on integration approaches and international mergers and acquisitions performance," International Studies of Management \& Organization, 41, 9-24.

Williams, C. and Lee, S.H. (2016), "Knowledge flows in the emerging market MNC: The role of subsidiary HRM practices in Korean MNCs," International Business Review, 25, 233-243.

Yin, R.K. (1981), "The Case Study Crisis: Some Answers," Administrative Science Quarterly, 26, 58-65. Yin, R.K. and Heald, K.A. (1975), "Using the case survey method to analyze policy studies,"

Administrative Science Quarterly, 371-381.

Yitzhack Halevi, M., Carmeli, A. and Brueller, N.N. (2015), "Ambidexterity in SBUs: TMT Behavioral Integration and Environmental Dynamism," Human Resource Management, 54, s223-s238.

Zhang, J., Zhou, C. and Ebbers, H. (2011), "Completion of Chinese overseas acquisitions: Institutional perspectives and evidence," International Business Review, 20, 226-238.

Zhu, W., Wang, G., Zheng, X., Liu, T. and Miao, Q. (2013), "Examining the Role of Personal Identification With the Leader in Leadership Effectiveness: A Partial Nomological Network," Group \& Organization Management, 38, 36-67. 